\title{
Non-conviction based sanctions: the Court of Justice v European Court of Human Rights, who decides?
}

\author{
Mo Egan \\ Dundee Business School, University of Abertay, United Kingdom*
}

\begin{abstract}
As the Lisbon Treaty enters into force the commitment to the creation of an Area of Freedom, Security and Justice is demonstrated through the expansion in the role of the Court of Justice of the European Union. This expansion is heralded by the Stockholm Programme as providing an opportunity to 'ensure consistency of interpretation' but the position of the Court of Justice in relation to the European Court of Human Rights (ECtHR) is yet to be clarified. In particular, the Stockholm programme emphasises the importance of indentifying and confiscating criminal assets. However, there are disparate practices across the EU as to how the proceeds of crime are recovered. Potential for human rights issues are particularly heightened in those systems which adopt non-conviction based sanctions. The Stockholm programme claims that the case-law of the Court of Justice and ECtHR will be able to develop 'in step' but conflict appears to be imminent. Taking the specific case of non-conviction based recovery of the proceeds of crime this paper will attempt to map the relationship and responsibilities of the Court of Justice and ECtHR post-Lisbon.
\end{abstract}

\section{Introduction}

Recovering the proceeds of crime has become an instrumental tool in the fight against transnational criminality. It is expounded frequently that this tool is fundamental because it removes the incentive and means to commit further criminal activity. However, the 'follow the money' approach to crime control raises human rights concerns because it interacts with the pre-trial investigative stage through asset restraint, the trial phase through criminal confiscation, and through concurrent and post-conviction civil recovery. The human rights protection that is available differs depending on which stage of the process you are at. Moreover, some Member States of the European Union have adopted more extensive recovery in the form of nonconviction based recovery (also known as non-conviction based forfeiture). Asset restraint and confiscation have been challenged as a violation of human rights obligations: For example, on grounds that they deprive an individual of their property in violation of Art.1.of Protocol 1. of the European Convention of Human Rights (ECHR), and in the case of restraint, arguably without a fair trial in violation of Art. 6. ECHR. However, civil recovery and other forms of non-conviction based forfeiture have received relatively little judicial attention. ${ }^{1}$

\footnotetext{
* This research is jointly funded by the Scottish Institute for Policing Research and the University of Abertay. This paper was presented at the UACES Policing and European Studies Conference, February 2011.
}

\footnotetext{
${ }^{1}$ Grayson v United Kingdom (2009) 48 E.H.R.R. 30; James v United Kingdom (1986) E.H.R.R 123. Also see joined cases C-402P and C-415/05P, Yassin Abdullah Kadi and Al Barakaat International Foundation $v$ Council of the European Union and Commission of the European Communities [2008] ECR 1 which concerns a challenge to the implementation of UN Security Council Resolutions concerning the freezing of assets of suspected terrorists. S/RES/1267 (1999); S/RES/1333 (2000) and S/RES/1390 (2002).
} 
The Lisbon Treaty has entrenched the European Union's commitment to human rights protection in Art. 6. of the Treaty of the European Union (TEU). It specifically states that the European Union 'shall accede to the European Convention for the Protection of Human Rights and Fundamental Freedoms.' 2 This would have a consequential impact on the relationship between the Court of Justice and the European Court of Human Rights: potentially allowing judgments of the Court of Justice to be appealed to the European Court of Human Rights. To date the European Court of Human Rights has been reluctant to review legislative acts of the European Union. However, as the European Union moves towards further expansion and consolidation of an Area of Freedom, Security and Justice the potential for the European Court of Human Rights to review European Union law is imminent. While the Stockholm Programme highlights the "protection of the rights of suspected and accused persons in criminal proceedings is a fundamental value of the Union, ${ }^{3}$ it goes on to emphasise the importance of improving the efficiency of confiscation calling upon Member States

and the Commission to use all available instruments be they fiscal, civil or criminal. ${ }^{4}$ This continued promotion of civil recovery mechanisms runs the risk of implementation by Member States that infringes human rights. Fear of such infringements could inhibit police and judicial cooperation amongst Member States. Consequently, this paper argues that the Lisbon Treaty and Stockholm programme have increased the tensions between the expansion of non-conviction based sanctions and the protection of human rights - which may result in a breakdown in policing cooperation as opposed to its bolstering.

As the relationship between the Court of Justice and the ECtHR remains complex the priority has to be making the system work. Ensuring an effective and efficient criminal justice system across the EU is inherently linked to monitoring and securing human rights protection. Conflict between the courts and infraction of the ECHR could be avoided if implementation or expansion of non-conviction based measures is accompanied by appropriate consultation with Member States who currently utilise such a system: focusing the discussion on how they have ensured the requisite human rights protections at all stages of the process. The paper begins by providing an overview of the criminalisation of the proceeds of crime. Using the illustration of the UK it demonstrates how such measures have been implemented. It moves on to analyse the responsibilities of the Court of Justice in relation to the protection of human rights prior to the Lisbon Treaty. Thereafter, it theorises how these responsibilities will develop as a consequence of the Lisbon Treaty and how this will impact on the relationship between the Court of Justice and the ECtHR. Finally, focusing on non-conviction based recovery the paper highlights the challenges resulting from the concurrent jurisdictions of the two Courts. It concludes that the best way to tackle this issue is to educate practitioners in the human rights protections ensured in Member States non-conviction based recovery systems.

\section{From territoriality to comity}

Traditionally criminal law is an area which has been inherently territorial. This means that a particular territory will criminalise activities which they consider out with the

\footnotetext{
${ }^{2}$ Art 6(2) TEU.

${ }^{3}$ O.J.2010 C $115 / 1$ at para 2.4 .

${ }^{4}$ O.J.2010 C $115 / 1$ at para 4.4 .5
} 
socially acceptable norms of that society. In addition, the consequences of engaging in those criminalised acts would also be dictated by that society: resulting in a variety of sanctions geared towards prevention, punishment or rehabilitation. With the advent of transatlantic travel to the invention of the internet, the criminal environment changed. When a perpetrator has taken part in a criminal activity in one territory he was able to find refuge in another. Moreover, he was able to remain in one territory while committing criminal activities in another territory. With the potential for perpetrators to exploit territorial criminal laws there was a call for States to acknowledge and respect each others' jurisdiction. The jurisdictional landscape has moved from territoriality to comity. Consequently, criminal law and cooperation mechanisms must work in tandem to facilitate the investigation and prosecution of such transnational criminal activity.

As the European Union has evolved it has produced a multitude of legislation creating a distinct European legal framework requiring participation and implementation by Member States. However, criminal law and procedure has remained somewhat disjointed due to Member States' desire to maintain sovereignty in an area which is closely linked to the identity of nations. This is usefully illustrated by the UK's negotiation of Protocol 30 discussed further below. However, as the Member States of the European Union have acceded to the Council of Europe's European Convention of Human Rights, acknowledging their desire to protect human rights through international obligations, their desire to criminalise and control activities is metered by integration of this human rights framework.

\section{Confiscating criminal assets}

Confiscation has been a crime control measure at the international level for decades. From 1961 it was adopted in relation to drug trafficking through the Single Convention on Narcotic Drugs. ${ }^{5}$ It provided a legal basis for the confiscation of 'drugs, substances, and equipment' used in the commission of offences created by the Convention. ${ }^{6}$ This provision was mirrored in the 1971 UN Convention on Psychotropic Substances. ${ }^{7}$ The importance of confiscation as a mode of crime control was emphasised again in the 1988 Convention Against Illicit Traffic in Narcotic Drugs and Psychotropic Substances (the 1988 Vienna Convention) where the Member States declared they were 'determined to deprive persons engaged in illicit [trafficking of drugs] of the proceeds of their criminal activities' and in doing so would remove their 'main incentive. ${ }^{8}$ ' Consequently, they expanded the use of confiscation from 'drugs, substances, and equipment' to 'proceeds.' ${ }^{9}$ ' Most importantly the 1988 Vienna Convention provided that in relation to confiscation, each party could consider reversing the burden of proof, placing it squarely on the shoulders of the accused. ${ }^{10}$ Since then confiscation has evolved further tackling a much broader range of criminality. The UN Convention against Transnational Organised Crime of 2000 (the 2000 Palermo Convention) provides that confiscation can be used in relation to proceeds derived from the offences covered by the

\footnotetext{
${ }^{5}$ As amended by the 1972 protocol amending the Single Convention on narcotic Drugs 1961.

${ }^{6}$ Art. 37. Single Convention on Narcotic Drugs 1961 as amended by the 1972 protocol.

${ }^{7}$ Art. 22(3). UN Convention of Psychotropic Substances 1971.

${ }^{8}$ Para 6 of the Preamble to the UN Convention against Illicit Traffic in Narcotic Drugs and Psychotropic Substances 1988. The European Union signed the Convention in June 1989 and formally confirmed its position in December 1990.

${ }^{9}$ Art. 5. UN Convention against Illicit Traffic in Narcotic Drugs and Psychotropic Substances 1988.

${ }^{10}$ Art. 5(7).
} 
convention. ${ }^{11}$ Broadly speaking this includes participation in serious crime ${ }^{12}$, or an organised criminal group, ${ }^{13}$ laundering the proceeds of crime, ${ }^{14}$ corruption $^{15}$ or obstruction of justice. ${ }^{16}$

While asset confiscation plays a large part in tackling serious and organised crime there is relatively little analysis of the human rights implications. The confiscation itself is only part of the process and can be preceded by a number of provisional measures such as asset restraint. The interaction of policing and judicial measures in the 'follow the money approach to crime control' is crucial in ensuring the protection of the individual's rights. ${ }^{17}$ The aims behind such measures are numerous but can be narrowed to the prevention of dissipation of assets or prevention of further criminality. Confiscation of the proceeds of crime presents an interesting challenge for critique since it straddles both the criminal and civil arenas across the EU. Confiscation has been justified on the grounds that it compensates society for the behaviour which has been determined as socially unacceptable. ${ }^{18}$ Moreover, such action reaffirms 'confidence in a fair and effective criminal justice system.' 19 Nevertheless, while the trend is moving ever further towards civil recovery, it has been argued by some commentators that this move to confiscation of assets through a civil procedure demonstrates a preference for the needs of the State over due process rights. $^{20}$

\section{Cooperation in investigation and enforcement}

Beyond criminalisation of the proceeds of crime, the implementation and enforcement of provisional measures and confiscation orders across jurisdictions are subject to additional international legislative action. In particular, the 1990 Council of Europe Convention on laundering, search, seizure and confiscation of the proceeds from crime, provides a legal basis for cooperation. This convention was heavily influenced by the 1988 Vienna Convention, and attempted to provide a 'complete set of rules, covering all stages of the procedure from the first investigations to the imposition and enforcement of confiscation sentences.' ${ }^{21}$ While it provides a number of definitions in Art. 1 it is drafted in such a way that it focuses on the goal of the measure as opposed to its title. This was to facilitate recognition between states where a request detailed a measure with a different name but otherwise was substantively the same. For example, where a 'confiscation' request detailed a 'forfeiture,' or a 'freezing'

\footnotetext{
${ }^{11}$ Art. 12. UN Convention against Transnational Organised Crime 2000. Signed by the European Union in December 2000 and approved in May 2004.

${ }^{12}$ Defined in Art. 2. of the UN Convention against Transnational Organised Crime 2000 as "conduct constituting an offence punishable by a maximum deprivation of liberty of at least 4 years or a more serious penalty."

${ }^{13}$ Art. 5.

${ }^{14}$ Art. 6.

${ }^{15}$ Art. 8.

${ }^{16}$ Art. 23.

${ }^{17}$ For a useful discussion see R.T. Naylor, 'Wash-out: A critique of follow-the-money methods in crime control policy', Vol. 32. No. 1,Crime, Law and Social Change, (2006) 1-58.

${ }^{18}$ P. Bean, Drugs and Crime, $3^{\text {rd }}$ Ed (Devon: Willan Publishing, 2008) at p164.

${ }^{19}$ A. Leong. Disruption of International Organised Crime: An Analysis of Legal and Non-legal Strategies, (Oxon: Ashgate Publishing Limited, 2007) at p138.

${ }^{20}$ L. Campbell, 'From due process to crime control - the decline of liberalism in the Irish criminal justice system,' 25 ILT (2007) 281. at p284.

${ }^{21}$ Explanatory Report to the Convention on Laundering, Search, Seizure and Confiscation of the Proceeds of Crime, ETS No.141, at para 10.
} 
order referred to a 'seizure,' this should not be a barrier to cooperation. Crucially, it is clear from Art. 13. that in the case of confiscation it does not have to be a result of criminal proceedings. It is sufficient that the proceedings are in relation to instrumentalities or proceeds. This means that the convention can operate in respect of a non-conviction based civil recovery.

Although the aim of the 1990 Convention was to facilitate cooperation to the widest possible extent it does provide for a number of grounds for refusal, detracting from the force of the provisions. ${ }^{22}$ The 1990 Convention provides that a Member State can refuse to cooperate if 'the action sought would be contrary to the fundamental principles of the legal system of the requested party. ${ }^{23}$ More specifically a Member State can refuse to cooperate in the execution of a confiscation order where the request does not relate to a previous conviction. ${ }^{24}$ So ultimately, while it can provide a legal basis for cooperation in non-conviction based recoveries - parties are not bound to cooperate.

Where a dispute has arisen as to application and interpretation of the Convention, the Convention provides that the parties should ideally settle matters through negotiation but could, if they wished, refer the matter to the European Committee on Crime Problems who could make a decision which would bind the Parties or to the International Court of Justice. ${ }^{25}$ It would be possible where the underlying reason behind the refusal is concern for human rights protection that the matter be referred to the ECtHR. ${ }^{26}$ However, since the European Union has used the principles of the 1990 Convention as the basis for a number of legislative measures in the field of justice and home affairs there is potential for the Court of Justice to have concurrent jurisdiction (albeit on a different legal basis). ${ }^{27}$

Significantly, the 2005 Warsaw Convention which amends the 1990 Convention provides for mandatory cooperation between States on civil recovery. ${ }^{28}$ It makes provisions for the monitoring and implementation of the Convention. ${ }^{29}$ For example, where a dispute as to interpretation of the Convention arises the Conference of the Parties can be approached for an opinion. If the dispute continues, as with the 1990 Convention, the parties can go to arbitration or the International Court of Justice. Again, the ECtHR would have jurisdiction if human rights concerns were to be the foundation of the refusal to cooperate. As yet it has not informed EU legislation (in contrast to the 1990 Convention). The Warsaw Convention's impact has been somewhat disappointing as Member States have been slow to ratify it. Despite a flurry of ratifications in 2010 there are still 15 EU Member States, including France,

\footnotetext{
${ }^{22}$ Art. 18. Convention on Laundering, Search, Seizure and Confiscation of the Proceeds from Crime, Strasbourg, 8.XI.1990.

${ }^{23}$ Art. 18. para 1(a).

${ }^{24}$ Art. 18. para 4(d).

${ }^{25}$ Art 42. para 2.

${ }^{26}$ Art. 32 and Art. 33. Convention for the Protection of Human Rights and Fundamental Freedoms as amended by Protocols Nos. 11 and 14 .

${ }^{27}$ For example: Council Framework Decision 2005/212/JHA of 24 February 2005 on Confiscation of Crime-related Proceeds, Instrumentalities and Property and Council Framework Decision 2006/783/JHA of 6 October 2006 on the application of the principle of mutual recognition to confiscation orders.

${ }^{28}$ Art. 23(5) Council of Europe Convention on Laundering, Search, Seizure and Confiscation of the Proceeds from Crime and on the Financing of Terrorism Warsaw, 16.V.2005.

${ }^{29}$ Art . 48. Council of Europe Convention on Laundering, Search, Seizure and Confiscation of the Proceeds from Crime and on the Financing of Terrorism Warsaw, 16.V.2005.
} 
Germany, Italy, and the United Kingdom who have yet to do so. This is particularly surprising in relation to the UK and Ireland in that they have implemented some of the most rigorous civil recovery mechanisms. While the Convention does appear to provide a more robust obligation to cooperate, grounds of refusal are still accommodated albeit on a more limited scope. ${ }^{30}$

Member States have been encouraged to produce guidance as to how their assets recovery systems work. ${ }^{31}$ Unfortunately, the production of such guides has been somewhat lacklustre. ${ }^{32}$ Operational requirements are such that time is of the essence in investigations. Consequently, where a Member State is refusing cooperation the matter may have to be put on hold while alternative investigative solutions are found. At the judicial stages the way in which investigations have been carried out is of fundamental significance to the disposal of the case. It is crucial that in an ever expanding area of freedom, security and justice the policing agencies share knowledge of their systems to prevent a reluctance to cooperate and the potential judicial ramifications. This must be done through an institutionalised training mechanism as opposed to on a case by case basis because if not, operational priorities will take over, forcing Member States to find alternative solutions as opposed to dealing with a particular issue. Such ambiguity between Member States understanding of non-conviction based systems of recovery could force the ECtHR into reviewing such systems.

\section{Recovery across the EU: UK Implementation}

In the UK confiscation is currently dealt with in the Proceeds of Crime Act 2002. The UK consists of three different jurisdictions and the legislation is divided accordingly. Part 2 deals with confiscation in England and Wales, Part 3 deals with Scotland, Part 4 deals with Northern Ireland but Part 5 makes provision for civil recovery across the UK. This legislation implements the majority of measures required by EU law. In making these provisions consideration has been given to human rights safeguards in accordance with the Convention of Human Rights and the Human Rights Act 1998 which implements the Convention in the UK domestic law. ${ }^{33}$ These safeguards aim to balance the right of the individual to peaceful enjoyment of their property and the interests of society in assets obtained from illegal activity. As with other nonconviction based systems of recovery, the UK was clear in the drafting of their legislation that these measures were ECHR compliant. They grounded this view on the premise that the measures are not directed at the individual (in personam) but at the origin of the property (in rem). ${ }^{34}$

While the UK has considered human rights protection in the drafting and application of their legislation, they appear to remain fearful of the Lisbon Treaty's incorporation of protection of human rights through the Charter of Fundamental Rights of the European Union. Indeed, the UK and Poland were concerned that such an extension

\footnotetext{
${ }^{30}$ Art. 28. Council of Europe Convention on Laundering, Search, Seizure and Confiscation of the Proceeds from Crime and on the Financing of Terrorism Warsaw, 16.V.2005.

${ }^{31}$ Art.2(1).98/699/JHA Joint Action on money laundering, the identification, tracing, freezing, seizing and confiscation of instrumentalities and the proceeds from crime.

${ }^{32}$ M. Borgers, and J. Moors, 'Targeting the proceeds of crime: Bottlenecks in International Cooperation.' European Journal of Crime, Criminal law, and Criminal Justice, (2007) 1-22, at p14.

${ }^{33}$ A. Leong. Disruption of International Organised Crime: An Analysis of Legal and Non-legal Strategies, (Oxon: Ashgate Publishing Limited, 2007) at p138.

${ }^{34}$ Joint Committee on Human Rights Eleventh Report (2004) at para 18.
} 
may have a knock on effect on the jurisdiction of the Court of Justice and consequently, they negotiated a specific provision stating that its jurisdiction would not be extended to finding 'the laws regulations or administrative provisions, practices or action of Poland or of the United Kingdom are inconsistent with the fundamental rights and principles that it reaffirms. ${ }^{35}$

The UK is thoroughly aware that their system of civil recovery is incompatible with some of those Member States who have a civil code. ${ }^{36}$ This raises the issue whether these Member States could refuse to cooperate with the UK on the basis of that civil code. Nevertheless, the UK is adamant that their system of civil recovery is ECHR compliant and consequently, they are doing everything in their power to promote this amongst Member States. To that end the UK, in consultation with the Serious Organised Crime Agency (SOCA), have finalised a model agreement which is used to facilitate civil recovery bilaterally with individual countries. ${ }^{37}$

The UK are not alone in their desire to promote civil recovery: there is international commitment to extending police and judicial cooperation: The Financial Action Task Force (FATF) are consulting on a proposal to require that countries assist with requests based on foreign non-conviction based confiscation orders in certain circumstances. ${ }^{38}$ So far, domestic challenges have been disposed of with little furore meaning there is still little guidance from either the Court of Justice or the European Court of Human Rights as to the human rights implications of non-conviction based recovery. ${ }^{39}$

Currently, decisions by the ECtHR must be 'taken into account' by domestic courts on Convention rights issues but such decisions are merely persuasive and are not binding on national courts. ${ }^{40}$ However, there is extensive case law as to the meaning of 'take into account' and indeed the UK national courts have interpreted this as in effect binding them unless there are special reasons not to do so. ${ }^{41}$ Nevertheless potential for conflict arises because decisions by the Court of Justice on the validity, meaning and effect of any EU law instruments or Treaty do bind national courts with no ambiguity. ${ }^{42}$ If conflict was to arise between the Court of Justice and the ECtHR the national court would have to apply the Court of Justice decision. This would change following EU accession to the ECHR.

\footnotetext{
${ }^{35}$ Article 1, Protocol No.30 on the application of the Charter of Fundamental Rights of the European Union to Poland and to the United Kingdom. This derogation now also extends to the Czech Republic in accordance with Conclusions 3 of the European Council of 29 and 30 October 2009.

${ }^{36}$ The Government reply to the Nineteenth Report from the House of Lords European Union Committee Session 2008-2009 HL Paper 132, Cm 7718 at para 202.

${ }^{37}$ Ibid at para 205.

${ }^{38}$ FATF (2010) 'The review of the Standards - Preparation for the $4^{\text {th }}$ Round of Mutual Evaluations', October, p13.

${ }^{39}$ The Scottish Ministers v McGuffie and others, [2006] CSOH 34. In this case McGuffie argued that the application for an interim administration order and warrant for inhibition and arrestment were retrospective penalties in violation of Art. 7. ECHR. The Court's disposal hinged on categorising the measure as civil or criminal and the determination of whether the measures constituted a penalty. Lord Kinclaven found that the measures constituted a regime for the civil recovery of property obtained through unlawful conduct and not a regime of punishment.

${ }^{40}$ S2(1)(a), Human Rights Act 1998.

${ }^{41}$ See in particular Secretary of State for the Home Department $v F$ [2009] UKHL 28 per Lord Hoffmann at para.69. and $R$. (on the application of Ullah) $v$ Special Adjudicator [2004] 2 A.C. 323 p.26 (UKHL) per Lord Bingham of Cornhill at para.20.

${ }^{42}$ S3(1) European Communities Act 1972 as amended by European Union (Amendment) Act 2008.
} 


\section{Pre-Lisbon Human Rights Jurisdiction of the Court of Justice and its' relationship with ECtHR}

Initially the Court of Justice's role focused on economic matters. ${ }^{43}$ However, as European integration increased and following the creation of the Schengen acquis, the Court's role spilled over into the criminal law arena. The third pillar, which dealt with 'cooperation in the field of justice and home affairs' as established by Title VI of the Maastricht Treaty, provided that conventions adopted under this pillar could furnish the Court of Justice with appropriate jurisdiction to interpret their provisions, and to rule on disputes in relation to their application. ${ }^{44}$ This meant that each convention would have to independently give jurisdiction to the Court, leading to a fragmented jurisdictional landscape. Bolstering the area of freedom, security and justice, the Amsterdam Treaty strengthened the third pillar, which was renamed 'provisions on police and judicial cooperation in criminal matters.' ${ }^{45}$

Framework Decisions were the main legislative instruments of the third pillar. ${ }^{46}$ Member States were resistant to the creation of an EU criminal law and the EU had to find a suitable way to acknowledge this. Accordingly, prior to the Lisbon Treaty, Framework Decisions did not have direct effect. ${ }^{47}$ In terms of Art 34(2)(b) TEU of the Treaty of Nice, such decisions were binding on national courts only 'as to the result to be achieved' but allowed the national courts to have discretion as to 'choice of form and methods.' It was later clarified by the Court of Justice that this meant that these decision would have indirect effect. ${ }^{48}$

In terms of Art. 35 TEU (pre-Lisbon) the jurisdiction of the Court of Justice in policing and judicial cooperation fell into three categories: an optional preliminary ruling procedure; ${ }^{49}$ limited judicial review ${ }^{50}$ or a procedure for resolving disputes between Member States. ${ }^{51}$ Each of these provisions would theoretically allow the Court of Justice to evaluate validity and implementation against those human rights which are protected as general principles of EU law. However, the case law of the Court of Justice demonstrates that the Court of Justice are of the view that 'rights' can be limited where it is in the interests of the EU to do so. ${ }^{52}$ Such an assessment on the scope of rights may present conflict between the Court of Justice and the ECtHR.

Although the third pillar housed the main criminal law provisions there was further legislative action which would influence the development and implementation of criminal law in both the first and second pillars. As the binding nature of the instruments used in each pillar differs so too does the jurisdiction of the Court of Justice and, consequently, the relationship with the ECtHR.

\footnotetext{
${ }^{43}$ V. Mitsilegas, EU Criminal Law (Oxford and Portland, Oregon: Hart publishing , 2009) at p6.

${ }^{44}$ Art K.3(2)(c). (now Art. 19 TEU)

${ }^{45}$ V. Mitsilegas, EU Criminal Law (Oxford and Portland, Oregon: Hart publishing, 2009) at p12.

${ }^{46}$ Ibid at p26.

${ }^{47}$ Art 34 (2)(b) TEU (which has now been repealed by the Lisbon Treaty discussed in more detail below)

${ }^{48}$ Case C-105/03 Maria Pupino, ECR [2005] I-5285 at para 43.

${ }^{49}$ Art. 35(1) TEU. (which has now been repealed by the Lisbon Treaty).

${ }^{50}$ Art. 35(6) TEU. (which has now been repealed by the Lisbon Treaty).

${ }^{51}$ Art. 35(7) TEU. (which has now been repealed by the Lisbon Treaty). See Carruthers, S. (2009) 'The Treaty of Lisbon and the reformed jurisdictional powers of the European Court of Justice in the field of justice and home affairs.' E.H.R.L.R. 6. pp784-804 for a more extensive discussion of these provisions. ${ }^{52}$ For example, Art. 17 of the Charter of Fundamental Rights of the European Union states that the right to property may be limited 'so far as is necessary for the general interest.'
} 
The doctrine of 'equivalent protection' established in the 1990s was an attempt by the European Commission of Human Rights to accommodate the autonomous legal order of the EU. ${ }^{53}$ The doctrine determined that Member States could exclude responsibility under the Convention where they had transferred power to an international organisation provided there was a mechanism which ensured compatibility with the Convention. In the case of the EU legal order they found that the role of the Court of Justice in reviewing the then EC acts for compatibility with fundamental rights provided this 'equivalent protection.' However, this doctrine will only protect Member States when they have done nothing more than implement their obligations as a member of the organisation. ${ }^{54}$ This remedy is open to criticism, although a Member State can elude the jurisdiction of the European Court of Human Rights on the grounds that they were implementing their obligations as a Member of the organisation, as the EU it is not a signatory to the ECHR so there is no accountability mechanism in relation to it. ${ }^{55}$

In the case of asset confiscation, freezing and restraint, the relevant EU legislation provides leeway for Member States to implement a wider range of measures and therefore could inadvertently lead to them stepping out with the protection of the 'equivalent protection' doctrine and into the jurisdiction of the ECtHR. The EU may argue that such measures are in the interests of the EU as a whole and consequently justify any limitations on the rights of individuals. However, the ECtHR may not take the same view. Considering that the EU cannot at this juncture be held responsible, as they are not a contracting party to the ECHR, the Member State may be held responsible for measures which have been implemented as a result of obligations to the EU. ${ }^{56}$

\section{Post-Lisbon: Expanded role of the Court of Justice}

The Treaty on the Functioning of the Union provides that the Court of Justice will have an extended jurisdiction that allows them to consider issues which arise between Member States or Member States and the Commission relating to the interpretation or validity of measures or decisions taken under the Treaties' provisions on Police and Judicial Co-operation in Criminal matters. ${ }^{57}$ It does not have jurisdiction to review issues which concern Member States' maintenance of law and order or the safeguarding of internal security. ${ }^{58}$ However, the Court of Justice case law demonstrates that where a Member State derogates from EU law through an administrative decision or primary legislation they have effectively brought the matter within the scope of EU law. ${ }^{59}$ Consequently, the Court of Justice could consider and

\footnotetext{
${ }^{53} M$ \& Co v Federal Republic of Germany (1990) 64 DR 138; C. Costello, 'The Bosphorous Ruling of the European Court of Human Rights: Fundamental Rights and Blurred Boundaries in Europe.' Vol. 6. No. 1. Human Rights Law Review (2006) pp 87-130 at p88.

${ }^{54}$ C. Costello, 'The Bosphorous Ruling of the European Court of Human Rights: Fundamental Rights and Blurred Boundaries in Europe.' Vol. 6. No. 1. Human Rights Law Review (2006) pp 87-130 at p100.

55 J. Callewaert, 'The European Court of Human Rights and the Area of Freedom, Security and Justice. 8, ERA Forum (2007) pp511-518 at p514.

${ }^{56}$ ECHR 18.2.1999 [GC], Matthews v United Kingdom, no 24833/94 at para 32.

${ }^{57}$ Article 240B, Treaty on the Functioning of the Union.

58 A. O'Neill. 'The Europeanisation of Scots criminal law,' Scottish Criminal Law (2008)Oct, pp11221134 at 1128 .

${ }^{59}$ Case C-260/89, ERT paras 41-42
} 
test the validity of their decision or legislative action against fundamental rights considerations.

The Court of Justice has repeatedly emphasised that national courts should give precedence to EU law when there is a conflict between national law and EU law. ${ }^{60}$ Consequently, a criminal or civil action could be defended on the grounds that the legal instrument on which it is based is a breach of EU law. ${ }^{61}$

While the Lisbon Treaty has facilitated an extension of jurisdiction (albeit a recognition of judicial activism evident in the case law) of the Court of Justice, in relation to reviewing criminal law, Art. 6(2) TEU also provides a legal basis for the European Union to accede to the European Convention of Human Rights. The effect is that if and when the European Union does accede, a judgment of the Court of Justice could be appealed to the European Court of Human Rights. This is promoted by the Council of Europe as an external review mechanism ensuring an independent assessment of human rights compliance. However, there are three significant hurdles to be overcome before this independence is fully embraced: Firstly, before the European Union can accede that matter must be agreed and implemented through an extensive legislative procedure. Secondly, as discussed above, the relationship between the Court of Justice and the ECtHR has been governed by the doctrine of 'equal protection' and although EU accession would establish a hierarchical relationship between these courts, it seems likely that there would be reluctance by the European Court of Human Rights to alter the status quo. Thirdly, aside from a desire to maintain good relations with the Court of Justice, the European Court of Human Rights is already suffering under the pressure of a back log of cases.

Taking these matters in turn, while the Lisbon Treaty facilitates the accession of the EU to the ECHR there is still a considerably lengthy legislative procedure to be undertaken. Once the accession agreement has been concluded by the Committee of Ministers of the Council of Europe it must then be agreed unanimously by the Council of the EU. Since all Member States of the European Union are also members of the Council of Europe it would appear that once the agreement is reached within the Council of Europe it will only be a formality for it to be agreed by the Council of the EU. After it has successfully completed these stages consent will be required from the European Parliament. However, where time may be lost is in the need for subsequent ratification by all 47 contracting parties to the ECHR. Moreover, Member States will have to do so in accordance with their respective constitutional requirements. While it may be true that at the inter-governmental level Member States are committed to accession there may be less commitment at the domestic level - resulting in delay. Given that Protocol 14 of the ECHR, which was wholly concerned with expediency, took 6 years to come into force it seems unlikely that accession of the EU will be completed in a shorter timescale. In the interim, the ECtHR must foster its relationship with the EU to ensure accession. ${ }^{62}$

Secondly, the abolition of the pillar structure and implementation of the Charter by the Lisbon Treaty effectively expands the 'equivalent protection' doctrine since it

\footnotetext{
${ }^{60}$ Costa v ENEL [1964] ECR 585 (6/64)

${ }^{61}$ A. O'Neill. 'The Europeanisation of Scots criminal law,' Scottish Criminal Law (2008) Oct, pp11221134 at $\mathrm{p} 1133$.

${ }^{62}$ Declaration on Art. 6(2) of the TEU annexed to the Final Act of the inter-governmental conference which adopted the Treaty of Lisbon in Brussels on 23 July 2007.
} 
enhances EU human rights protection potentially extending it to the Area of Freedom Security and Justice. If and when the EU accedes to the ECHR there may be reluctance by the ECtHR to exert its hierarchical relationship with the Court of Justice, unless this 'equivalent protection' can be shown to be 'manifestly deficient. ${ }^{63}$ This would maintain the status quo of the relationship between the two courts. ${ }^{64}$

Thirdly, as it stands in many cases the jurisdiction of the courts are concurrent and consequently it may be in the interests of efficiency for the ECtHR to step back and 'allow' the Court of Justice to proceed. It is well documented that the ECtHR has a backlog of cases which outstrip its capabilities. ${ }^{65}$ It has reached such a crisis point that it was necessary for the ECtHR to develop a procedural mechanism which would facilitate a faster turnover of cases and in addition allow for prioritisation of those most urgent. As noted above, this resulted in Protocol 14. which came into force in June 2010, a mere 6 years after it was adopted by Council of Europe Committee of Ministers. The Protocol introduced the possibility of a single judge making a decision as to admissibility of cases. ${ }^{66}$ It was anticipated that such a move would improve the efficiency of the Court. However, the results have been disappointing, there remains an annual deficit of 20,100 cases, being the difference between cases allocated and cases disposed of. ${ }^{67}$ While the ECtHR is under such pressure it cannot act as a truly independent reviewer of EU law as it only has capacity to cherry pick those cases which appear to be of most significance.

\section{Conclusion}

It has been highlighted that the Lisbon Treaty seeks to implement the EU commitment to human rights protection. It affirms the relationship between the Court of Justice and the ECtHR. However, as has been drawn out in this paper there are three hurdles to the ECtHR exertion of authority. First, accession to the ECHR is likely to be slow. Secondly, the removal of the pillar structure has in effect extended the jurisdiction of the Court of Justice in the area of freedom, security and justice meaning that the doctrine of 'equivalent protection' is extended. Thirdly, the ECtHR is already overburdened with cases and it not in a position to avidly review EU legislation.

On the 24 January 2011 the Presidents of the Court of Justice and the ECtHR issued a joint statement as to how the courts foresee their burgeoning relationship. ${ }^{68}$ Firstly, in applications where an action is raised by an individual against a measure adopted by and EU institution, following accession, they would be required to exhaust domestic remedies in accordance with Art. 35(1) of the ECHR. This would mean that the matter must go to the Court of Justice first and thereafter the ECtHR. Secondly, in

\footnotetext{
${ }^{63}$ M \& Co v Federal Republic of Germany (1990) 64 DR 138. ECHR 30. 6. 2005 [GC], Bosphorus v. Ireland, no. $45036 / 98$.

${ }^{64}$ See ECHR 30. 6. 2005 [GC], Bosphorus v. Ireland, no. 45036 /98. Where the ECtHR took a markedly different approach from Matthews United Kingdom, no 24833/94 - in that it focussed on the jurisdiction of the Court of Justice to provide protection, in Bosphorous the Court of Justice had jurisdiction to examine this secondary legislation and consequently provided 'equivalent' protection of human rights to that of the Convention.

${ }^{65}$ There are currently 139,650 cases pending. Analysis of Statistics 2010, ECtHR, Jan 2011.

${ }^{66}$ Art. 7. Protocol No. 14 to the Convention for the Protection of Human Rights and Fundamental Freedoms, amending the control system of the Convention Strasbourg, 13.V.2004

${ }^{67}$ Analysis of Statistics 2010, ECtHR, Jan 2011.

${ }^{68}$ Joint communication from Presidents Costa and Skouris (Strasbourg \& Luxembourg: ECtHR \& Court of Justice, January 2011).
} 
applications against acts adopted by the authorities of the Member State for the application or implementation of EU law, in accordance with Art. 267. TFEU, the matter may or must, be referred to the Court of Justice for a preliminary ruling. However, if the Member State has exercised discretion here and not referred the matter to the Court of Justice, the ECtHR could be called upon to review EU law.

Recognising, this gap in the relationship between the Court of Justice and the ECtHR the courts clarify that they are searching for a procedure which will respect the principle of subsidiarity and insure that the Court of Justice has the opportunity to review matters before the ECtHR do so. How this will be achieved remains to be seen.

The Stockholm Programme's promotion of the 'follow the money approach to crime control' increases the pressure on Member States to adopt such measures. These measures are viewed in some Member States with reservations as to their human rights compliance. Since the Lisbon Treaty emphasises the importance of such protection there may be reluctance by Member States to cooperate.

Current legislation facilitates a Member State's refusal to cooperate where it is against their national constitution - it may be that where a non-conviction based system is in place and a Member State seeks the cooperation of another Member State that the requested Member State refuses on human rights grounds. In these circumstances, although the Court of Justice may find that non-conviction based sanctions are in keeping with the observance of human rights law, this judgment may, following accession to the ECHR, be appealed to the ECtHR. Where previously the Court of Justice has found that certain rights may be limited in view of the interests of European citizens the same limitation may not be affirmed by the ECtHR.

Most recently Germany and Bulgaria notified the Council of implementation of Framework Decision 2006/783/JHA on the application of the principle of mutual recognition to confiscation orders. However, it is significant that both Member States have made declarations under Art. 7(5) of the Framework Decision not to recognise and execute confiscation orders that have been ordered under extended powers of confiscation under the law of the issuing State (Art. 2(d)(iv). It is fundamental that Member States share their systems with one another and highlight human rights safeguards so that cooperation is forthcoming when it is called upon.

It may be fair to say that some Member States simply do not have the necessary domestic provision to share information/evidence which may be used for civil proceedings but until Member States are fully appraised of how non-conviction based recovery works they will not be in a position to make the relevant changes. It is crucial that Member States engage with the calls to produce guidance on their own system that can easily be accessed by relevant Member States. The number of organisations involved who may potentially hold relevant information or be able to provide appropriate advice is extensive. Europol, Eurojust, the European Judicial Network, CARIN, Egmont, as well as the Asset Recovery Offices, are all participants in the European criminal justice landscape and Member States should exploit these agencies' knowledge. ${ }^{69}$

\footnotetext{
${ }^{69}$ Council Decision 2007/845/JHA. (Asset Recovery Offices)
} 
It may be that policing agencies within the different Member States are so aware of human rights obligations following the Lisbon Treaty that they tie their own hands behind their back. By refusing to cooperate with Member States who administer nonconviction based recovery on such grounds they potentially force the Court of Justice to review matters and post EU accession to facilitate further review by the European Court of Human Rights. 